Acta vet. scand. $1973,14,81-91$.

From the Department of Reproductive Physiology and Pathology, Veterinary College of Norway, Oslo.

\title{
MORPHOLOGICAL AND ULTRASTRUCTURAL STUDIES OF MOOSE SPERMATOZOA
}

\author{
By \\ Kjell Andersen
}

\begin{abstract}
ANDERSEN, KJELL: Morphological and ultrastructural studies of moose spermatozoa. Acta vet. scand. 1973, 14, 81-91. - Epididymal spermatozoa from moose were studied in phase contrast, light interference and electron microscope. Some samples taken from cauda were diluted and frozen in liquid $\mathrm{N}_{2}$. The motility of the sperms after thawing was good.

The concentration of spermatozoa in cauda was calculated to $10 \times 10^{6}$ cells per $\mu l$.

Morphologically the spermatozoa of moose were found to be quite similar to those collected from bulls. The length of the sperm head was found to be approx. $8.8 \mu$ and the average maximal width $5.2 \mu$. The average length of the tail was $54.7 \mu$ and the entire length of the spermatozoon varied from 60 to $64 \mu$. Compared with sperm cells from bulls the moose spermatozoa appeared to have a somewhat shorter and broader head and a slightly shorter tail.

The migration of the cytoplasmatic droplets, which was found to be completed in caput, seemed to follow the same pattern as in bulls and boars. As found in these species there was also in the moose a higher frequency of secondary abnormalities in the spermatozoa from cauda than in those from the other parts of epididymis.

Studies of the fine structure of the moose spermatozoa seemed to indicate that these are of the same type as the spermatozoa of bulls, rams and boars. In sagittal sections the sperm head was thin, but in contrast to the sperm cells of the species mentioned above no typical waist-like narrowing in the equatorial region was found. The equatorial segment also seemed to be less arched than in the spermatozoa from bulls, rams and boars. Otherwise, no principal difference was found between ultrastructure of the moose spermatozoa and that of the spermatozoa collected from domestic species.
\end{abstract}

moose spermatozoa; morphology; ultrastructure.

The breeding season of the moose (Alces alces L.) is in the autumn. The sexual activity of the female is in this country usually restricted to the last $2-3$ weeks of September and the first half of October (Wildhagen 1962). The gonadal function and gamete production of the female moose have been the subjects of earlier investigations carried out in Finland (Koivisto \& Rajakoski 1966) and in Sweden (Markgren 1969). 
Studies of the gamete production in the male in order to evaluate the breeding capacity and to establish a basis for spermatological comparison with related domestic species have to the author's knowledge not been published. Studies of the testicular function of reindeer (Meschaks 1966) indicate that the spermatogenesis in adult animals of this species occurs primarily in connection with the sexual season. If this should be the case also in moose it would not bring about any difficulties in regard to the collection of material since the hunting in this country generally coincides with the mating season.

\section{MATERIAL AND METHODS}

The material was collected $1-3$ hrs. post mortem from three animals in the autumn 1969 and one in 1971. The weight of one testicle varied between individuals from 110 to $140 \mathrm{~g}$.

Smears for morphological studies were made from the contents of the ductus epididymidis in the caput, corpus and cauda region. The morphology of the spermatozoa was studied in a phase contrast microscope as well as in a light interference microscope at a magnification of 450 and $1000 \times$. Measurements of the different parts of the sperm cells were performed by use of a micrometer. Totally 30 cells were measured. The ductus contained a considerable number of sperm cells suspended as a fluid of a thick creamy character, especially in the cauda. After incising the cauda, samples of this fluid were collected by use of a Pasteur pipette and diluted about 1:100 with Tris extender containing $8 \%(\mathrm{v} / \mathrm{v})$ glycerol and $20 \%(\mathrm{v} / \mathrm{v})$ egg yolk (Davis et al. 1963). The spermatozoa were equilibrated with glycerol at $4^{\circ} \mathrm{C}$ for $3 \mathrm{hrs}$. and then frozen in polyvinylchloride-straws in $\mathrm{N}_{2}$ vapour (Jondet 1964) and stored in liquid $\mathrm{N}_{2}$. Frozen samples were thawed at $75^{\circ} \mathrm{C}$ for $10 \mathrm{sec}$. (Aamdal \& Andersen 1968) and tested for motility - using a phase contrast microscope.

Preparations for electron microscopy were made from thawed samples after centrifugation ( $1000 \times \mathrm{g}$ for $5 \mathrm{~min}$.). The sediment was fixed in a solution of $1 \%$ osmium tetroxide for $60 \mathrm{~min}$. at room temperature (Millonig 1961). After dehydration in alcohol the material was embedded in Epon (Luft 1961). Epididymal spermatozoa were also prepared directly without dilution and freezing. In this case the material was prefixed in a $3 \%$ glutaraldehyde solution in Millonig's phosphate buffer for $45 \mathrm{~min}$. and 
then fixed in a solution of $1 \%$ osmium tetroide. After this procedure, which also took place at room temperature, the material was dehydrated in acetone at $0^{\circ} \mathrm{C}$ and embedded in araldite. The sections of preparations made from frozen as well as fresh epididymal sperm cells were cut with glass knives on an LKB ultrotome and stained with lead acetate (Dalton \& Ziegel 1960) and further with uranyl acetate (Watson 1958). Electron microscopy was carried out by use of a Siemens Elmiskop IA, at primary magnifications of $10,000-30,000 \times$.

\section{RESULTS}

Calculations based on sperm counting of diluted samples in a haemocytometer indicated that the number of sperm cells in the posterior part of cauda was about $10 \times 10^{6} \mu \mathrm{l}$.

As found in other species (Bishop \& Walton 1960) the spermatozoa appeared to be nearly immotile when taken directly from the ductus epididymidis. After dilution with the Tris extender the cells exhibited a high degree of matility. The motility of the spermatozoa was also maintained to a great extent after thawing of frozen samples stored at various periods of time in liquid $\mathbf{N}_{2}$.

\section{Morphology}

In phase contrast microscope (Fig. 1) the head of the moose spermatozoa appeared to be oval with slight flattening of the anterior margin thereby presenting a somewhat spade-like shape similar to that of the sperm head of cattle (Götze 1949). The anterior borderline of the equatorial segment seemed to be less arched and the segment as a whole also slightly less distinct than in the spermatozoa of cattle and sheep.

The average length of the head was measured to be $8.8 \mu$ $(8.1-9.1 \mu)$ and the average width $5.2 \mu(4.9-5.3 \mu)$. The filamentous tail generally showed a marked distinction betwen the middle piece and the main piece (Figs. 2, 3 and 4). The latter was gradually tapered towards the end piece. The total length of the tail averaged $54.7 \mu(51.3-57.6 \mu)$, while the length of the entire spermatozoon varied between 60 and $65 \mu$.

The migration of the cytoplasmatic droplet can be seen by comparing the spermatozoa in Figs. 2, 3 and 4 . In the caput the droplet was found in a proximal position, situated close to the 
base of the head. In the corpus it was usually attached to the posterior part of the middle piece, a position which was still maintained in some spermatozoa collected from the cauda, whereas others had completely lost the droplets in the cauda.

Morphological abnormalities were observed rather frequently especially in the spermatozoa collected from the cauda. Tail defects in particular were more often found here than in the other parts of the epididymis.

\section{Electron microscopy}

As in other species (Bishop \& Walton) the head of the moose spermatozoon appeared to consist predominantly of nuclear material limited by the nuclear membrane. The nucleus was thin when cut sagitally giving the sperm head a typical paddle-shaped appearance. The nucleus appeared to consist of heavy condensed chromatin substance showing some small irregular less electron dense areas (Figs. 5, 6 and 7). The nuclear membrane, also called the nuclear envelope, was found to be a double structure actually consisting of two triple-layered membranes (Fig. 12). It was, however, usually very difficult to discern the innermost membrane because of its nearness to the heavily stained chromatin of the nucleus.

Anteriorly the nucleus was covered by the double walled acrosome and posteriorly by a structure generally referred to as the postnuclear cap (Bishop \& Walton).

As found in the spermatozoa of other species, the acrosome presented itself as a unit composed of one inner and one outer component referred to as the inner and the outer membranes or zones, respectively (Austin \& Bishop 1958). The structure of the acrosome is shown in Figs. 5, 6 and 7. The inner membrane was found in close apposition to the nuclear envelope except at the anterior border where it projected from the surface forming an invagination into the acrosome and limited the so-called perforatorium or apical body (Figs. 5, 6, 8 and 9). This structure which was separated from the nucleus by the nuclear envelope consisted of a rather electron dense material. Posteriorly the inner membrane was found to be joined to the outer one which then extended anteriorly forming the outer limit of the acrosome called "galea capitis" (Blom 1964). The two zones were found to be lying close together for some distance forming the equatorial segment which, although somewhat inconspicuous, also 

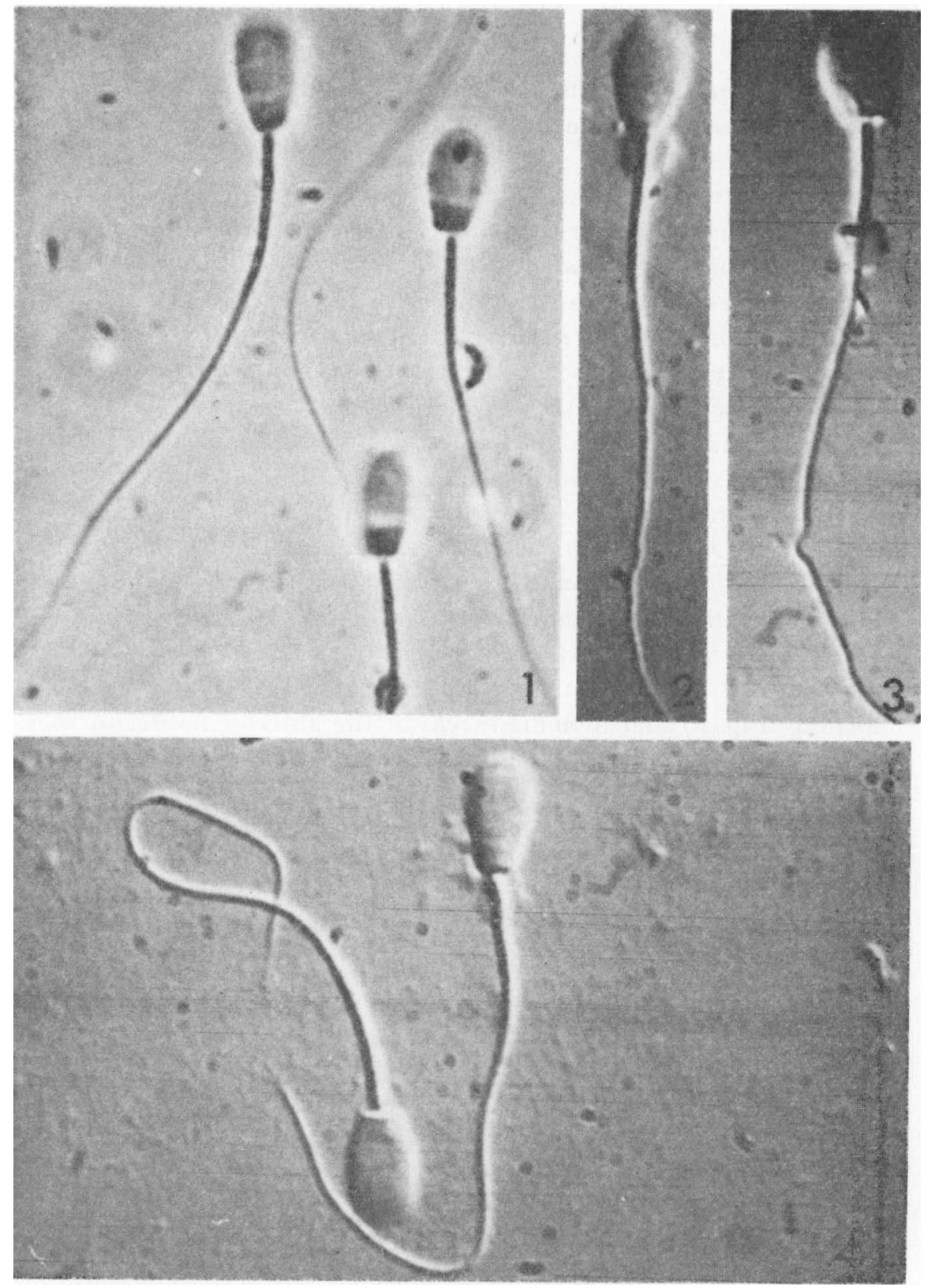

Figure 1. Epididymidal spermatozoa from moose. The hight of the equatorial segment is nearly the same straight across the head. Phase contrast. $1000 \times$

F i g u r e 2. Moose spermatozoa from caput epid. Light interference. $1000 \times$

F i g u r e 3. Moose spermatozoa from corpus epid. Light interference. $1000 \times$

Fig u r e 4. Moose spermatozoa from cauda epid. Light interference. $1000 \times$ 
could be seen in the light microscope resembling a belt giving a special refraction of the light (Fig. 1). This segment, and consequently the acrosome as a whole, was generally seen to extend further backwards on the convex side of the spermatozoon (Figs. 5 and 7 ). This is a feature which has also been found in the sperm of other species (Nicander \& Bane 1966). More anteriorly the two membranes diverged forming a space of varying size containing material of a somewhat inconsistent density. At the anterior margin the spermatozoa showed a more or less conspicuous thickening of the acrosome formed by an extension of the outer membrane. This extension was usually most pronounced at the convex side of the spermatozoa (Figs. 5, 6, 7 and 8).

The postnuclear cap presented itself as a rather dense lamina situated between the nuclear envelope and the cell membrane posterior to the acrosome (Figs. 5 and 7 ). The cytoplasmatic layer beneath the postnuclear cap was continuous with the subacrosomal substance which covered the anterior part of the nucleus and which was especially conspicuous in the perforatorium (Fig. 9) and to some extent at the anterior border of the equatorial segment (Fig. 5, 6 and 7).

The base of the sperm head formed a distinct implantation fossa covered by the nuclear envelope (Figs. 10 and 11). As found in spermatozoa of other species (Nicander \& Bane) the nuclear envelope appeared to continue down into the neck region probably forming a diverticulum or "skirt" around the base of the nucleus (Figs. 10, 11 and 12), similar to that described in bull sperm cells (Wooding \& O'Donnell 1971). In further accordance with the observations made by Wooding \& O'Donnell the diverticulum seemed to contain clumps of incompletely condensed nuclear material, so-called basal knobs on either side of the head (Figs. 11 and 12), and likewise several pores were found in the nuclear envelope (Fig. 12).

The cell membrane or plasmalemma which is supposed to be in close apposition to the outer zone of the acrosome (Fawcett 1958) was very often seen "ballooning out" thereby appearing to be free from the acrosome over its entire length (Fig. 7). On the other hand, in the region of the postnuclear cap, the plasmalemma seemed to remain more closely adherred. Quite frequently the plasmalemma was found to be completely lost over the entire sperm head. The implantation of the tail in the fossa at the base of the head frequently exhibited the same asymmetry as demon- 
strated in spermatozoa of other species (Nicander \& Bane). The striated material associated with the centriolar apparatus formed the main frame work of the connecting piece and could be discerned as a structure of varying distinctness (Fig. 11). In some sections the proximal centriole could be seen situated close to the base of the sperm head (Fig. 10).

In the middle piece posterior to the head-tail junction the tail filaments displayed the usual $9+9+2$ constellation of units (Figs. 13 and 14). Anteriorly the outer ring consisting of thick fibers was separated from the thinner filaments of the inner ring by the less electron dense matrix of the tail. As found in several other species (Bishop \& Walton) the three fibers designated numbers 1,5 and 6 were distinctly larger than the other filaments of the outer ring (Fig. 13). More posteriorly, near the beginning of the main piece, the two rings of filaments converged and, as in many other species (Fawcett 1970), the filament complex further back in the main piece appeared to consist of one concentric ring of nine double microtubules surrounding the central pair of single units (Fig. 15). In further accordance with the findings in a great number of other species (Bishop \& Walton) the symmetrical arrangement of the fibrils seemed to be lost in the end piece.

As shown in Figs. 13, 14, 16 and 17 the filaments were surrounded by the usual helix of mitochondria in the middle piece (Challice 1952). Around the fibrils of the main piece one could detect the tough protoplasma sheath containing rather distinct circumferentially oriented ribs commonly observed in the spermatozoa of other species (Bradfield 1955). This is demonstrated in Figs. 15 and 17. The two longitudinal columns of the sheath presented themselves as thickenings at opposite points in transverse sections of the main piece (Fig. 15).

\section{DISCUSSION}

The sperm concentration in cauda epididymidis of the moose is approximately the same as in cattle, in which the amount of epidymidal sperm cells has been determined in post slaughter material (Almquist et al. 1958). The weight of the testis seems to indicate that the reproductive capacity may be lower in the moose, although nothing definite can be said about the amount of spermatozoa per ejaculate and the number of sperm cells necessary to grant a sufficient rate of conception. 
The moose spermatozoa do not differ greatly in size from those of related domestic species when compared with the measurements reported by Ortvant et al. (1969). The sperm head is slightly shorter than that of the bull and somewhat longer than that of the ram. The maximal width of the sperm head is found to be greater than in any of these species. The tail appears to be somewhat shorter than in the spermatozoa from the domestic ruminants.

The migration of the cytoplasmatic droplet apparently takes place within the caput epididymidis since no sperm with proximal or intermediate droplets could be detected in the corpus. The process then appears to follow the same pattern as in the bull (Gustafsson \& Crabo 1971). Since section of the different parts of the caput have not been made, it is however impossible to determine in detail the course of the migration and exactly where in the caput the process is completed.

The rather high frequency of tail defects observed in the cauda is in accordance with the findings in boars (Gustafsson et al. 1970) and bulls (Gustafsson $\mathcal{K}$ Crabo). In boars it is suggested that the increase of sperm abnormalities observed during the passage through the epididymis may be associated with fluid resorption and higher osmotic pressure. This may also be the case in the moose.

According to the observations made by electron microscopy the moose spermatozoa show to a very great extent the same basic ultrastructural characteristics as the spermatozoa of domestic animals. The fine structure of the sperm head including the acrosome, the postnuclear cap and the basal plate was not found to differ fundamentally from that of other ruminants, horse and pig. As in other mammalian spermatozoa (Fawcett 1970) except those of some rodents (Bane $\&$ Nicander 1963) the marginal subacrosomal substance forming the apical body or perforatorium is of a rather insignificant volume and does not seem to contain any resistant structures, the term perforatorium therefore probably being somewhat misleading.

Comparisons based on the shape of the head lead to the assumption that the spermatozoa of the moose are of the same type as those of domestic ruminants and pig with elongated nucleus with the exception of the waist-like narrowing in the equatorial region reported by Nicander \& Bane (1966). This was not observed in moose spermatozoa. Transverse sections at different 
Kjell Andersen:

Morphological and ultrastructural studies of moose spermatozoa. 
F igure 5-1 7. Electron micrographs of moose spermatozoa.

Figure 5. Sagittal section of a sperm head with the nucleus (n), and with a marked acrosomal extention (ae) formed by the outer acrosomal membrane (o). Posteriorly this lies parallel and close to the inner membrane (i) forming the equatorial segment (es) which extends more posteriorly at the convex side of the sperm head (arrow). The subacrosomal material is rather abundant in the perforatorium (pf) and at the anterior border of the equatorial segment (x). The plasmalemma $(p)$ is closely applicd anteriorly to the acrosome and posteriorly to the postnuclear cap (pc). El.micr. $25,000 \times$

Figure 6. Sagittal section of two sperm heads. The plasmalemma (p) of the sperm head to the right is mostly intact while this membrane is lost in the left sperm head. El.micr. $30,000 \times$

F i g u r e 7. Sagittal section of a sperm head where the plasmalemma (p) extends from the surface of the acrosome (a) but is still closely applied to the postnuclear cap (pc). The nucleus contains a lighter area anteriorly (arrow). El.micr. 10,000 $\times$

F i g u r e 8. Sagittal section of the foremost part of a sperm head. In some areas the plasmalemma ( $p)$ extends from the outer membrane of the acrosome (o). The acrosomal extention (ae) is most conspicuous at convex side of the spermatozoa. The inner membrane of the acrosome (i) separates from the nuclear envelops (ne) at the tip of the nucleus and projects into the acrosomal extention forming the perforatorium (pf). El.micr. $45,000 \times$

F i g u r e 9. Sagittal section of a sperm tip passing through the acrosomal extention (ae) and the perforatorium (pf) which is bounded by the inner acrosome membrane (i) and separated from the nucleus by the double nuclear envelope (ne). The plasmalemma is lost. El.micr. $90,000 \times$

Figure 10 . Sagittal section of the posterior part of the sperm head and of the neck region. The proximal centriole (pc) is situated centrally in the connecting piece. The nuclear envelope can be discerned as a limiting membrane in the implantation fossa and also more posteriorly forming a kind of diverticulum (arrow) or "skirt" around the connecting piece. El.micr. $45,000 \times$ 

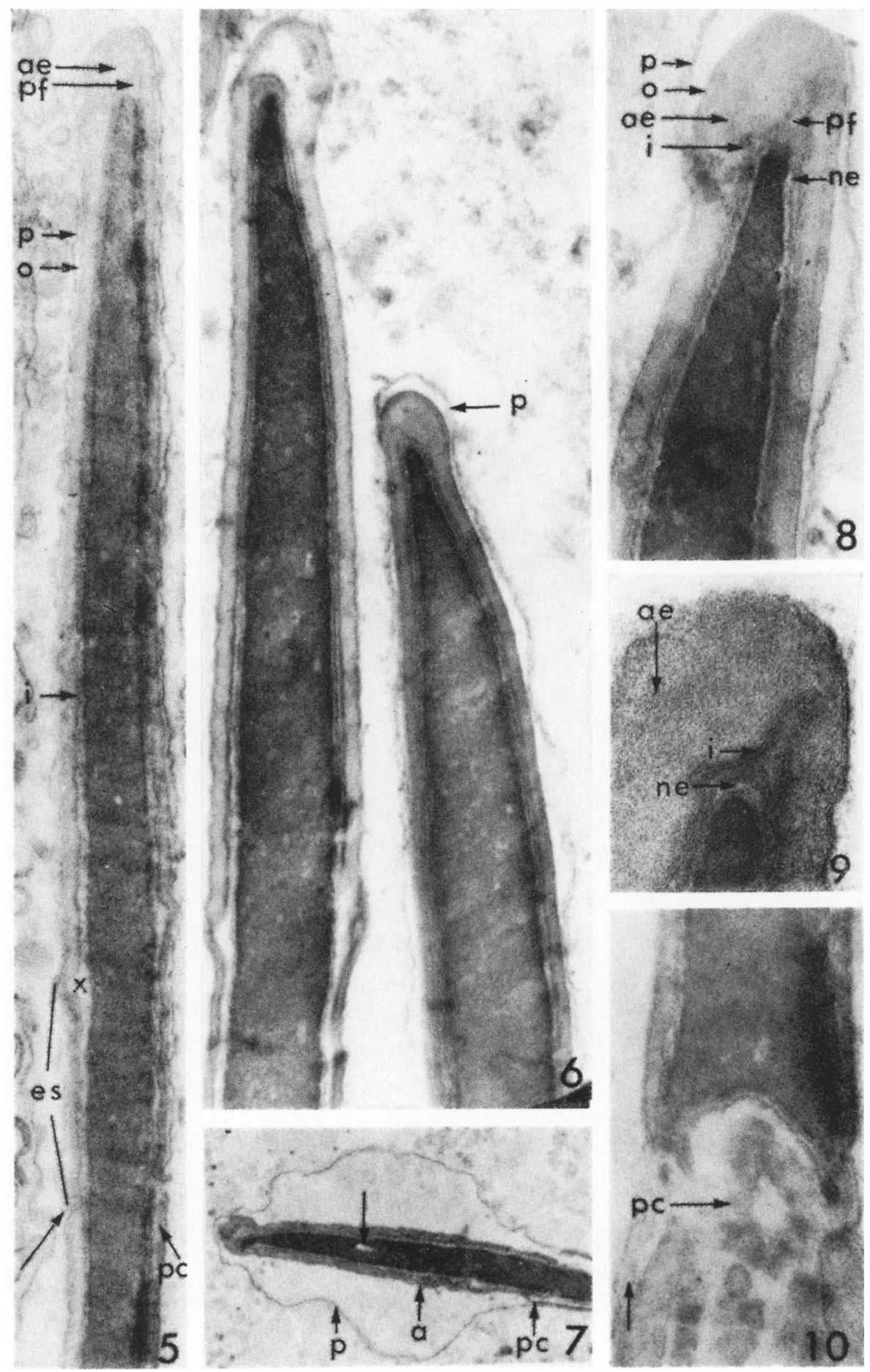
Figure 11. Horizontal section of the posterior part of the sperm head and of the neck region. The striated material of the connecting piece (c) is placed asymetrically in the implantation fossa (if). The diverticulum of the nuclear envelope (arrows) containing the basal knob material (b) is seen on both sides of the head lateral to the connecting piece. El.micr. 45,000 $\times$

F ig u re 12. Parasagittal section of the base of a sperm head showing the diverticulum of the nuclear envelope (ne) surrounded by the plasmalemma ( $p$ ) and containing the basal knob (b). Pores (arrows) can be seen in the nuclear envelope. The double structure of this membrane is here clearly visible. El.micr. $45,000 \times$

F i g u r e 13 . Transverse section of the middle piece (anterior part). The outer nine filaments are thick and conspicuously separated from the inner nine which surround the central pair (cp). Of the outer filaments numbers 1,5 and 6 are distinctly larger than the others. The filaments are enclosed by the mitochondrial helix $(\mathrm{m})$ and the plasmalemma (p). El.micr. $30,000 \times$

F i g u r e 14. Transverse section of the middle piece (posterior part) still showing the two rings of fibrils around the central pair, the distance between them, however, being smaller than in the anterior part. The fibrils are still surrounded by the mitochondrial helix $(\mathrm{m})$. The light material enclosing the sperm tail is presumably the cytoplasmatic droplet, its migration along the middle piece being completed. The substance, which is limited by a distinct membrane $(\mathrm{mb})$, contains some alveolar cytoplasmatic structures (arrows) probably of mitochondrial origin. El.micr. $30,000 \times$

Figure 15. Transvere section of the main piece with the axial filament system consisting of one ring of nine double fibrils surrounding the central pair. The subunits of each doublet can be discerned as two microtubules, one having a more electron dense lumen than the other. The fibrils are bounded by the protoplasma sheath (ps) containing two longitudinal columns (l). The plasmalemma (p) adhere more or less closely to the protoplasma sheath. El.micr. $50,000 \times$ 


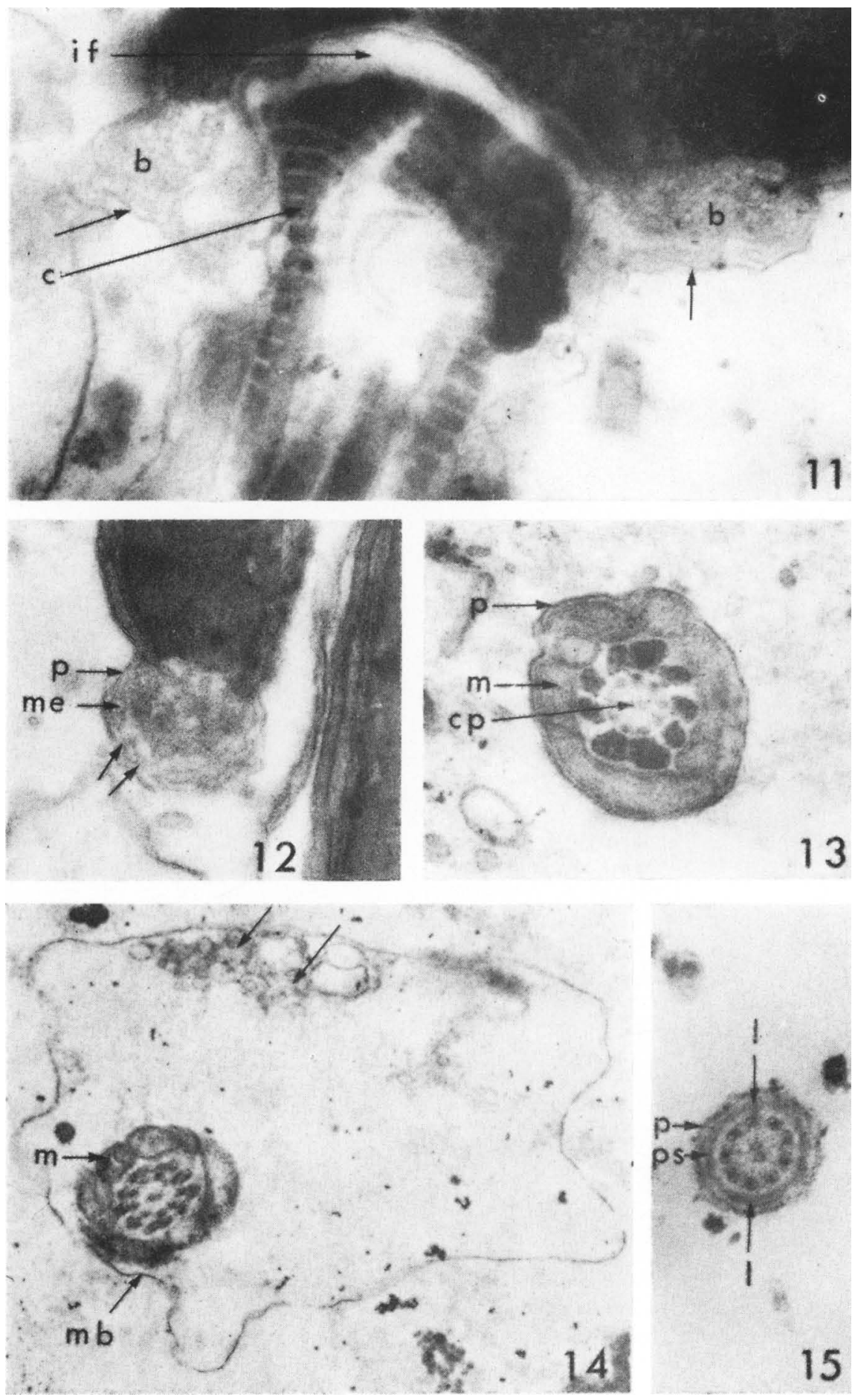


Fig u r e 16. Longitudinal section of the middle piece showing the filament system surrounded by the mitochondrial helix $(\mathrm{m})$. The plasmalemma $(p)$ is intact only on one side of the section. El.micr. $45,000 \times$

F i g u re 17. Longitudinal section at the junction of the middle piece and the main piece. The filaments of the latter are bounded by the protoplasma sheath (ps) with its ribs cross sectioned. The plasmalemma $(p)$ is rather irregular in outline. El.micr. 45,000 $\times$ 


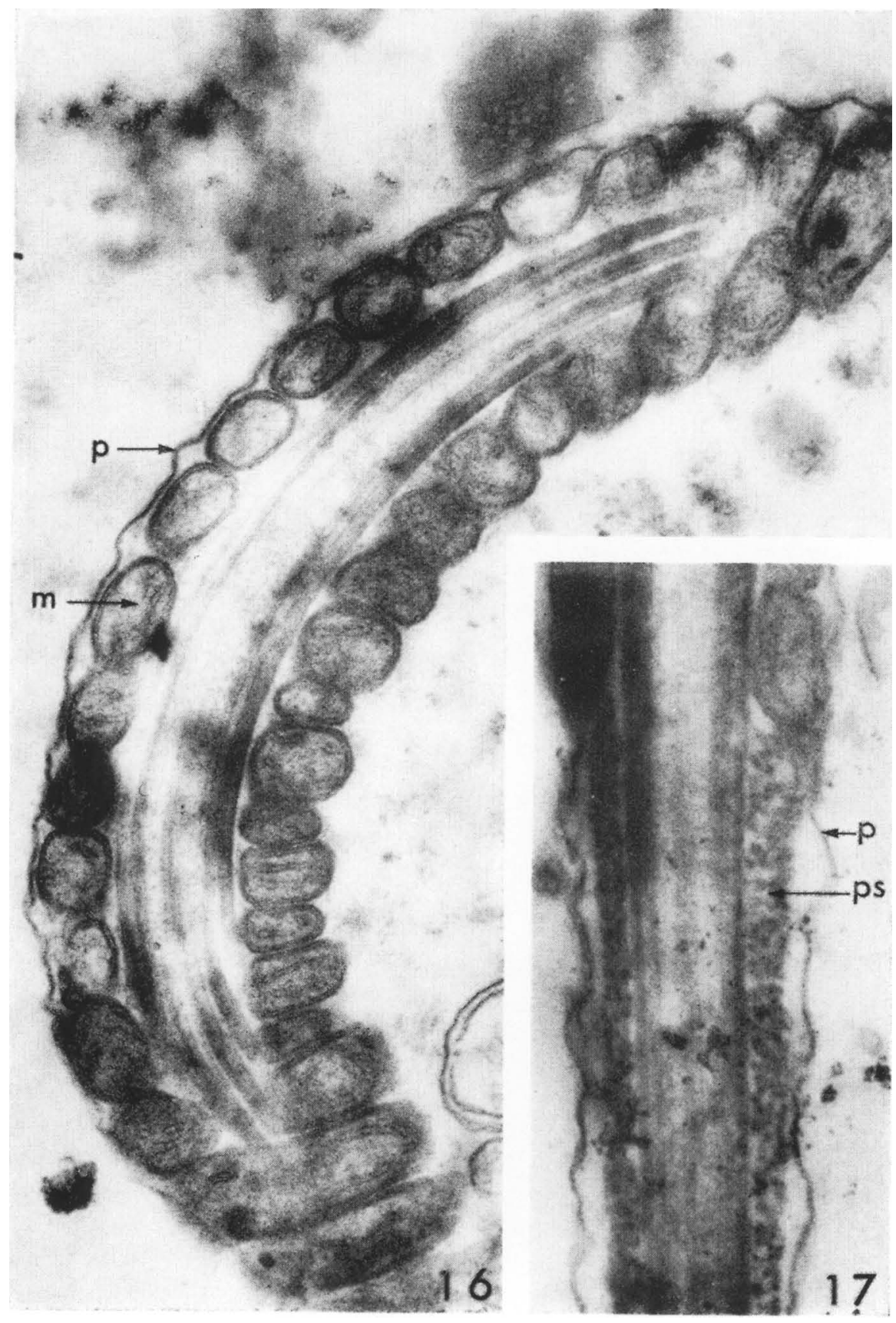


levels of the acrosome did not show the varying bilateral extension of the equatorial segment as found in domestic ruminants (Nicander \& Bane). This probably accounts for the less arched appearance of this segment found in the light microscope in the moose spermatozoa.

The marginal thickening of the acrosome due to the extension of the outer membrane quite often seemed to be slightly more pronounced in moose spermatozoa than in those collected from bulls. This acrosome thickening was, however, subject to considerable variation in size, probably depending on how it was sectioned.

The ultrastructure of the connecting piece and the tail was not found to be principally different from that of other mammalian spermatozoa.

As a whole ultrastructural studies can not be considered as a method easily applicable for the purpose of differentiation between moose spermatozoa and those of related domestic species.

A systematic comparison between ultrastructural details of fresh and frozen sperm cells has not been performed in this work. In accordance with the observations in human spermatozoa (Pedersen \& Lebech 1971), cells with swelling of the acrosome and loss of the plasmalemma in the acrosomal region seemed, however, to be found more frequently in the frozen samples than in those prepared immediately after collection.

\section{REFERENCES}

Aamdal, J. \& K. Andersen: Fast thawing of semen frozen in straws. Zuchthygiene 1968, 3, 1, 22-24.

Alnquist, J. O., R. P. Aman \& W. T. O'Dell: Sperm reserves of dairy bulls as determined by depletion trials and post slaughter sperm counts. J. Dairy Sci. 1958, 41, 733.

Austin, C. R. \& M. W. H. Bishop: Some features of the acrosome and perforatorium in mammalian spermatozoa. Proc. roy. Soc. B. 1958, 149, 234.

Bane, A. \& L. Nicander: The structure and formation of the perforatorium in mammalian spermatozoa. Int. J. Fertil. 1963, 8, $865-866$.

Bishop, M. W. \& A. Walton: Spermatogenesis and the structure of mammalian spermatozoa. In Marchall's Physiology of Reproduction ed. Parkes. Longamans, London 1960, vol. 1:2, p. 1-129.

Blom, E.: The galea capitis as part of the acrosome cap in the bull sperm. Rep. 5th Int. Congr. Animal Reprod., Trento 1964, vol. 4, $655-660$. 
Bradfield, J. R. G.: Fibre patterns in animal flagella and cilia. Symp. Soc. exp. Biol. 1955, 9, 306.

Challice, C. E.: Some observations on the morphology of spermatozoa by electron microscopy. Proc. Soc. Study Fertil. 1952, 4, 21.

Dalton, A. J. \& R. F. Ziegel: A simplified method of staining thin sections of biological material with lead hydroxide for electron microscopy. J. biophys. biochem. Cytol. 1960, 7, 409-410.

Davis, J. S., R. W. Bratton \& R. H. Foote: Livability of bovine spermatozoa at $5,-25$ and $-85^{\circ} \mathrm{C}$ in Tris-buffered and citrate-buffered yolk-glycerol extenders. J. Dairy Sci. 1963, 46, 333-337.

Fawcett, D. W.: The structure of the mammalian spermatozoa. Int. Rev. Cytol. 1958, 7, 195-235.

Fawcett, D. W.: A comparative view of sperm ultrastructure. Biol. Reprod. 1970, Suppl. 2, 90-127.

Gustafsson, B. \& B. Crabo: Några morfologiska egenskaper hos tjurspermier i olika avsnitt av bitestikeln. (Some morphological characteristics of bull spermatozoa at different levels of the epididymis). Nord. Vet.-Med. 1971, 23, 114-118.

Gustafsson, B., B. Crabo \& S. Einarsson: Morphology of the spermatozoa and composition of the plasma in the boar epididymis. Proc. XIth Nord. Vet. Congr., Bergen 1970, 241.

Götze, R.: Besamung und Unfruchtbarkeit der Haustiere. (Insemination and sterility in domestic animals). Verlag M. \& H. Schaper, Hannover 1949, 113-116.

Jondet, R.: Congelation rapide du sperme de taureau conditionne en paillettes. (Rapid freezing of bull sperm in paillettes). Rep. 5th Int. Congr. Animal Reprod., Trento 1964, vol. 4, 463-468.

Koivisto, I. \& E. Rajakoski: Förekomsten av gula kroppar samt äggcellernas fertilisation och migration hos älg (Alces alces) i Finland. (The occurrence of yellow bodies and the fertilization and the migration of ova in the moose (Alces alces) in Finland). Proc. 10th Nord. Vet. Congr., Stockholm 1966, vol. I, 184-188.

Luft, J. H.: Improvements in epoxy resin imbedding methods. J. biophys. biochem. Cytol. 1961, 9, 404-414.

Markgren, G.: Reproduction of moose in Sweden. Viltrevy - Swedish Wildlife 1969, 6, 129-299.

Mechaks, P.: Säsongvariationer i testikelmorfologi hos ren (Rangifer tarandus scandinavicus). (Seasonal variations of testicular morphology in reindeer). Proc. 10th Nord. Vet. Congr., Stockholm 1966, vol. I, 192-195.

Millonig, G.: Advantages of phosphate buffer for $\mathrm{OsO}_{4}$ solutions in fixation. J. appl. Physiol. 1961, 32, 1637.

Nicander, L. \& A. Bane: Fine structure of the sperm head in some mammals with particular reference to the acrosome and the subacrosomal substance. Z. Zellforsch. 1966, 72, 496-515.

Ortvant, R., M. Courot \& M. T. Hochereau: Spermatogenesis and morphology of the spermatozoon. In Reproduction of Domestic Animals. X sec. Ed., H. H. Cole \& P. T. Cupps, ed., Acad. Press, New York and London 1969, 251-276. 
Pedersen, H. \& P. E. Lebech: Ultrastructural changes in the human spermatozoa after freezing for artificial insemination. Fertil. and Steril. 1971, 22, 125-133.

Watson, M. L.: Staining of tissue sections for electron microscopy with heavy metals. J. biophys. biochem. Cytol. 1958, 4, 475-478.

Wildhagen, Aa.: Elgen. (The moose).In Elgen i Norge. (The moose in Norway). Ed. P. Hohle. Mjølner Forlag Oslo 1962, vol. I, 13-34.

Wooding, F. B. P. \& I. M. O'Donnell: A detailed ultrastructural study of head membranes of ejaculated bovine sperm. J. Ultrastruct. Res. $1971,35,71-85$.

\section{SAMMENDRAG \\ Morfologiske og ultrastrukturelle undersøkelser av elgspermier.}

Spermier fra bitestikkelen hos elg blev unders $\varnothing$ kt i fasekontrast-, interferens- og elektronmikroskop. Endel materiale fra cauda epididymidis blev fortynnet og frosset ned i flytende $\mathrm{N}_{2}$. Etter opptining viste spermiene god motilitet.

På grunnlag av tellinger $\mathrm{i}$ haemocytometer blev spermieinnholdet i cauda beregnet til ca. $10 \times 10^{6}$ celler pr. $\mathrm{mm}^{3}$.

Morfologisk viste elgspermiene stor likhet med spermier fra okse.

Ved bruk av mikrometer ble lengden av spermiehodet målt til ca. $8,8 \mu$, og den maksimale bredde til ca. 5,2 $\mu$. Gjennomsnittslengden av halen var $54,7 \mu$, og total lengde av spermiene varierte mellom 60 og $64 \mu$. Sammenlignet med oksespermier har elgspermiene noe kortere og bredere hode og litt kortere hale. Migrasjonen av protoplasmadråper ble funnet avsluttet $i$ caput og synes dermed stor sett å følge det samme mønster som hos okse og råne. I overensstemmelse med forholdene hos disse fant en også hos elg et høyere antall sekundære spermieabnormiteter i cauda enn i de $\varnothing v$ rige avsnitt av bitestikkelen.

Elektronmikroskopiske unders $\varnothing$ kelser av ferskt og opptint materiale viste at elgspermiene stor sett er av samme type som spermier fra okse, vær og råne. Spermiehodet var langt og smalt i sagitalsnitt, men synes å mangle den innsnevring av kjernen som er påvist innenfor ekvatorial-segmentet hos spermier fra de nevnte arter. Dette segmentet var muligens også noe mindre buet fortil enn hos okse-, værog rånespermier. Ultrastrukturen av spermienes forskjellige deler for$\emptyset$ vrig viste ingen prinsipielle avvikelser fra det som tidligere er funnet hos domestiserte arter.

(Received April 12, 1972).

Reprints may be requested from: Kjell Andersen, Department of Reproduction Physiology and Pathology, Veterinary College of Norway, Oslo Dep., Oslo 1, Norway. 